\title{
広島県における明治期学校運動会の考察
}

\author{
鶴 网英 一* \\ （昭和50年 8 月 5 日受付）
}

\section{A Nature of the School Athletic Games in Meiji Era in Hiroshima Prefecture}

\author{
Eiichi TSURUOKA \\ (Hiroshima University)
}

明治期に扣ける広島県の学校運動会の变遷を検討して, 欧米には例をみない学校行事といわれている運動会の 特算を明らかにしようとした。考察結果仕次のように要䄪される。

1. 学校運動会は体育奖励のために始められ，初期の数年間はこの性格が比较的純精に維持された.

2. 1890年頃から学校遇動会はその民衆動員的性格のため様々飞利用され, 学校行事から地域社会の行事へと 变筫を余儀なくされた。

3. 1900年以降，運動会の教育性の回復を求めて批判が高まるが，教育の枠組を越えてしまった運動会は，教 育関係者の努力にあかかわらず，実質的には变化しなかった。

This is an attempt to articulate the characteristics of the school athletic games in Japan, a kind of school-sponsored athletic activities which has no counterparts in European and American school activities.

The tentative conclusions derived from this study are as follows:

1. The athletic games were originated on purpose to supplement and promote the physical education. And this orientation had been maintained rather purely during the first several years.

2. From about 1890 , the athletic games had been used for non-educational purposes, because of their own popular mobilizing nature, and were necessitated a transformation of their nature from one of school activities to one of community activities.

3. From 1900, this transformation had been under a growing criticism which aimed at the restoration of original educational orientation of the athletic games. But by that time, they had acquired the attributes which were beyond the framework of education, and therefore, in spite of many educators' efforts, their non-educational perversion continued without substantial changes. (Eiichi TSURUOKA : A Nature of the School Athletic Games in Meiji Era in Hiroshima Prefecture, Research Journal of Physical Education, Vol. 20, No. 3, Dec., 1975 pp.167 176.) 


\section{はじめに}

明治期の運動会についてかなり早い時期に問題 提起をしているのは岸野雄三27)23)である．岸野は 連動会が欧米の影響を受けて生まれたすのであり ながら，日本独自なすのとして発展することに注 目して，運動会か「競技的要素」「嫃楽的要素」 および「デモンストレーション的要素」を骨子と していることをあげ，その独自性をわが国の市民 社会の未熟さに求めょ5としている。

今村荌雄は，「十九世紀に於ける日本体育の研 究」 ${ }^{23)}$ に扒いて，明治期の運動会に触れている. これは「大日本教育会雑誌」に揭载された運動会 について，(1)開催時期，(2)開催拒式，(3)種目，(4) 場所，(5)運動会の貢献などの項目について分析・ 柃䞑を加点たものである。しかしながら，対象と している時期か， 1884 年から 5 年間に限られてい ることや，選ばれた少数の運動会であることなど から，朋治期を通しての運動会の把暒には問題を 残している.

この今村の運動会の取り上げ方を踏㜔して，地 う体奇史に適用したものに，平野稔の「大分県に 㲿る明治体育史の研究一連動会, 遠是一」 ${ }^{14)}$ 古る。大分眊共立教育会機関誌の1885年から1912 自までに揭载された連動会について，「運動会が 時代けよび社会的背裴のけで発達する過程を明ら かに与る」たかの考祭がなされている。平野は今 朴の考繁項回に加之て，「運動会に関する所感・ 急見」を取り上げ，また「時代区分」をして明治 期定通しての年代的特徽の㭘討を試及ている。

これらいらなれば「今村風」29)の運動会史研究 に对して，近代スポーッの受容の代打着目して 連動会を取り上げているのが，荒井貞光の「日本 人之スポーツについての一考祭—学校運動会の 壁员上社会的意味一」」である。荒井は近比の 村落共问体に执いて命まれた避びの思想と連動会 との結びつきを追求しょうとする。しかしなが ら，運動会の社会的意味の展開に性急であるあま り，運動会そのbのの検剖がやや不足している.

また，山本信良・今野敏彦の「近代教育の天皇 制イデオロギー」50)は, 明治期における儀式, 遠 足, 到学旅行, 展覧会, 学芸会, 運動会等の学校
行事について，天皇制イデオロギーとの関連にお いて集大成を試みたるのである。この5ち運動会 については，今村同様「大日本教育会雑誌」揭載 の軍動会を中心に検封を進め, 明治初期の小学校 運動会の特色として，「旗奪」「隊列運動」にみ られる軍事的色彩，售賞制度，祭り的性格等を指 摘し，利用される運動会を強調する。ただ，1880 年代の運動会が中心となっているために，明治期 を通しての変喜には視点が向けられていない。

以上，運動会に関する主要な先行研究について 概観したが，筆者の運動会についての問題意識を 述へてておたい。

「学制」に始まるわが国の近代教育において， 体育が定着するまでにはかなりの迁余曲折を経な ければならなかったことは周知のとおりである。 たとえば，尋常小学校における「体操」の取り报 いについても，必須科目・随意科目をくりかえし て，教科として固定するのは，1900年の小学校令 改正以降のことであった。つまり「江户時代の教 育的要素の連続体として接する素地のなかった」 51)「体操」は，単なる上からの制度改革だけでは 容易には定着しなかったのである。この制度と契

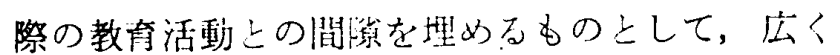
い光ば，西欧の体育・スポーツの受容搷取の過程 に打ける“计間項”として, 明治期の学校運動会 を評価することができるのではないか，運動会に 関心を寄せる第一の問題である。

次に，明治期の体育尖研究においてしばしば指 摘されるとこらであるが，個々の学校において 「体操」がどの上らに消化されて教育活動として 展開されたのかしい5笲把握にかかわる問題が ある。特定の学校の「校務[1誌」,「学校沿革誌」 あるいは地方の教奇雑誌等によって,「体操」の 実態を告げる史料に接することができるが，これ らは概して断片的かつ部分的であって，ある時期 の，またある地力の体有の概要を把握するのに は，必ずしも十分ではない。このよ5な意味にお いて，学校運動会は淔接的ではないにしても，学 校体育の実情を時にかなりリアルに反映する性質 のものとしてみることができるのではないか，運 動会への関心の第二の点である。

さらに，学校運動会が単なる学校行事ではなく 
て，いわゆる町ぐるみ・村ぐるみの地域社会におう ける年中行事的性格をもつものであることはよく いわれることであるが，学校運動会が学校から地 域社会へ拡大されていく過程はいかなるすのであ ったのか，とりわけ，地域社会の伝統的レクリェ ーションとはどのよ5なかかわりをすつのか. 学 校運動会についての第三の問題点である。

およそ以上のような問題意識から，明治期にお ける広島県の学校運動会を取り上げて, 次の項目 を中心に考察を試みたい。

（1）初期学校運動会の性格

(2) 学校運動会の变質過程

(3) 学校運動会の定着過程

\section{I運動会の系竲}

わが国の運動会の発祥に関してしばしば引用さ れるのは，海慗兵学等の「競闘遊戯会」(1874年) や札幌堆学校の「遊戯会」(1878年)，あるいは東 京大学の「陸上競技会」（1883年）である。しか しながら，運動会の地方への伝播よいう点では， 「小学校に於ける体育上の実際的施設之運動会」 の著者たちが，運動会の起源に関して，「明治 14， 5 年頃体操伝習淅に战て開催せる競技会なるすの を以て蓄矢とす」 ${ }^{6)}$ と述へているよ5に，体操伝 習所总会場としてて行なわれた運動会に注目すべき であろ5．坪井玄道は当時を圆想して次のよ5に 説明する。

「各学校に体操科を篗くことになったが，体操 の教師が呞ないので……各官立学校は体操伝習 所まで生徒を連机て来てやった。各学校の運動 会の如きも最初は伝習所で催 5 したが，伝習所 の卒業生が追い追い垎学校に配直されるように なって，体操も運動会もだんたん自分の学校で やるようになった.」32)

この伝習所を会場とする運動会は，周知のとお り体青奖㳩を標榜して開催さ礼たものである。し かし，同じく体育猉励を謳いながらも，「東京体

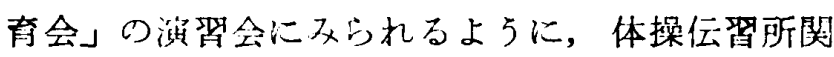
係者の日頃の修練結果䓘発表主るとい5内容のも の上，「東京府体有装淤会」に掠けるよ5に，体

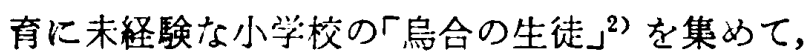
体育の普及啓蒙を図万弓とするものとでは，その
性格には若干の相違があった。

「東京体育会」の体操演習会における主要種目 は,

「亞鈴体操」「棍棒体操」「器械体操」「障碍 物競走」「フートボール」「旗拾競走」「二人 三脚競走」「袋脚競走」「戴車競走」「球投競 走」「旗取返競走」「銃翖試合」「人馬競走」

「棒脚競走」「高跳競走」「幅跳競走」「徒競 走」「弓術」「ペースボール」

などであった。これを東京大学の陸上競技的種目 を中心とした運動会と比較すれば，自らの性格は 明らかであろ5。つまり伝習所における運動会 は，学校体育の普及装励を目さし，具体的には普 通体操を重視したものであった。そして体操伝習 所卒業生の全国への配䈯 ${ }^{25}$ を若え併せると，この 体操伝習所系譜の運動会が地力にお沙る運動会の モデルとなったものと考えられる。そして上記種 目の多くが，明治期学校運動会の中心的種目とし て各地方へ普及していくのである。

\section{II 初期学校通動会の性格}

（1）明治前期に扮计る広鼠県の体等事情

広島県に打汀る運動会の考察に先立って，明治 初期の体淯事情に触れておきたい。1873年の「改 正小学教則」において初めて「体操」が具体的に 示されたのであるが，このいわば学校体育の発足 当初に，「体操」を実際に指導し得たのは，東京 を中心とするごく一部の学校に限られていた。広 寊県のばあい，たしかに 1876年の「学事報告」34) が述べるよ5に，「下等小学教則」に「体操」を あげて，「体操図二依テ之ヨ授ク」と規定しては いるものの，これ态もって広島県においても「体 操」が実施されていたと速断することはできな い. 何上りも「体操図」がこの当時，広島県に配

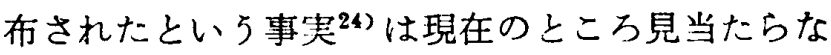
いし，また後述する師範学校の実情を考えれば， この洋風の「体操」を誰が教えるのかとい5問題 にまず值面したのである。一般的にい,って，小学 校体育はかりに行交わ机ていたとしても，きわめ て低調であったといえょ5。「山県郡教育誌」は このへんの事情を適切に㜔明する。

$r . . . .$. 併しこの场山県郡の各学校は校舎さへ民 
家を筫借したるもの多く，專用校舎を有するす の極めて稀なる位であるから勿論運動場の設備 はない，加え教員は紋附羽織袴を着用し，下駄 を穿ちて出勤する。生徒す亦長袖の袂のある衣 服を着用し，草履若くは木履を穿って出席する 有様である。そこで学制教育令時代は体操末教 課時代と称してよいのである.」影（傍点筆者， 以下下同じ)

一方，1874 年に発足した広島師範学校において 6，「学科日課表」35)に「課外に毎日体操三十分」 と規定しているが，1875 年の同校年報が告げるよ 5に，「従来体操ノ制末タ完全ナラサル 以以更

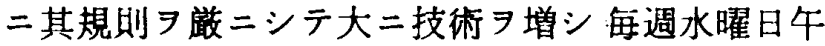
後生徒 $シ$ 演習シ其身 7 壮康ナラシム」 ${ }^{36)}$ とい5 状態であった。そしてこの「生徒ヨシ演習」せし めたのは，たとえば体育に熱心であった矢部校長 自らが指導した揧剣 ${ }^{19)}$ の類のものであった，当時 の卒業生が回顧する「和服にタスキがけ」20) とい 5 「体操」の実態は，中央のそれとはかなりかけ はなれたものであったといわなければならない。 このようなことから広島県学事年報 ${ }^{371}$ は，1881 年 および 82 年とくりかえして，「将来施設上必須， 件」として「体育习拡張」することを報告せねば ならなかった。そして具体的には，82年 7 月，小 学校教員を対象とする「体操」の講習会を開催し て，よ5やく「体操」指導への対㤁を始めたので ある。

ところで明治前半期における学校体育の定着過 程において，決定的とも思える影響力を与えたの は，ほかなら奴1883年の幑兵令改正である。この 改正によって示された中等学校以上の官立学校の 步兵操練科卒業証畫所有者に対する優遇措置は， これら藷学校に対して必然的に何らかの対応策を 促すものであった。 1883 年および 84 年の広島県学 事年報 ${ }^{38}$ 'は，「将来施設上須要ノ件」として「県立 学校体操科中二歩兵操練 7 加ヘントスル事」を報 告し，実祭には85年 9 月，県立学校に步兵操練科 を設けて，その指導を広島鎮台の陸軍士官に委啒 している。つまり広島県においては，「学校令」 に先立って，微兵令改正への対応とい5形で，中 等学校以上の学校に, 「兵式体操」が導入されて いたのである。
（2）広島県学校運動会の原型

広島県における本格的な運動会は，1886 年 2 月 開催の「県立学校小学校生徒大運動会」に始ま る.現代からみればやや時期外れに行なわれたこ の運動会は，前述の「歩兵操練」の 6 力月の訓練 成果を発表し，併せて新しく始まる「体操」の普 及奖励を目さすすのであった，当時の広島県師範 学校長萗是三郎の報告する゙)この運動会は，広島 鎮台練兵場を会場とし，県立学校（師範学校，中 学校, 医学校, 農学校) 生徒357名, 広島区内小学 校生徒 1347名が参加した大規模なるのである。そ の運動遊戯種自は炏のとおりであった。く( )内 の数字は演技者数を示す>

県立学校生徒の部

「蕣鈴体操」(150)，「棍棒体操」(30)，「球 竿体操」(150)，「木環体操」(60)，「兵式体 操」(45)，「競走旗取」(全員)，「障碍物飛 越」(45)

小学校生徒の部

「徒手体操」(350)，「噚鈴体操」(400)，「球 竿体操」(200)，「競走旗取」（全員）

これを一見すれば，「普通体操」を重視した伝 習所系譜運動会の地方版之い5 日象を与兄る。し かしながらここの運動会の正副「審查長」に前述 の「歩兵操練」を指導していた鎮台の士官・下士 官があたり，また「兵式体操」種目は演技者が少 数であるにもかかわらず最も長時間が割り当てら れたことを考え併せると，この運動会は陸軍が主 導するとい5色彩が浱厚であって，「普通体操」 重視とはいい切れない側面をもっていた。

（3）初期運動会の特幑

「県让学校小学校生徒大運動会」の開催から 1890 年頃までの数年間は, 広島県運動会史の初期 とみなすことができる。この時期の運動会はいわ ゆる学校運動会に限定され，運動会を行なった学 校も限られていた。この萠芽期における小学校を 中心とする運動会について，いくつかの特徽をみ ていきたい。

まず第一に，この時期の運動会は校外の「神社 の境内」「河原」「公園」「空地」等において開催 されるのが普通であった。このよ5なことから， 学校から会場までは，たとえば，「生徒を男女に 
区分隊列を組み受持教貣之を引卒し午前十一時半 学校を発す而して前に校名を記したる大旗を翻へ し毎組に組長什長各小旗を持ち生徒は皆弁当を風 呂敷に巻き肩より脇に取り行装最とも柽便に整へ り荷車には大釜手桶萎其他遊觑の引網羽子板逮 金環笑を積载せり途を爱宕町に取り…... 5情景が展開されたのである．明治期の運動会が しばしば「「長途運動」「遠足運動」とも呼称さ れたのは，会場までの遠足あるいは行軍が運動会 にはつきすのであったためであり，運動会と遠足 とは共存していたのが当時の実情である.

次に初期の学校運動会は単一の学校が開催する 例はきわめて稀であって，多くのばあい，数校が 合同して開催する「連合運動会」の形式がとられ ている，これは一つには当時の一校当りの児童数

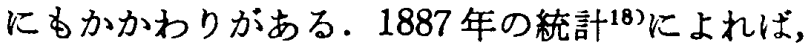
広島県下の小学校数 882 校, 棇児童数は 99,778名 であり，一校当りについては児童数 113 名，教員 数1.8名であった．数字が示すよ5に，一校単独で 運動会を開催することは困難であり，勢い数校が 合同せさるをえなかったのである，そしてこの合 同の仕方は，小学校教員の年次練習会や月次練習 会の地域区分の基準となった「小学校連合規則」 の区分に準じたばあいが多い：このいくつかの町 村にまたがった「連合運動会」の開催は，とくに 農村における村落共同体的風俗習慣にやがて变化 をるたらす一つの要因ともなるものであることに 注意したい。

第三の特徽は，運動会種目には一般的傾向とし て「兵式体操」と「遊戯」が取り上げられていた ことである。周知のとおり1886年以降明治年間を 通じて，「普通体操」「兵式体操」「遊戲」が「体 操」の主内容であったが，当初，地方の現場にお いては，「教則大綱」どおりに授業が行なわれて いたわけではない，学校令公布当時の学校体育の 実情はたとえば次の如きすのであった。

「森文相の体操猉励時代に入りては柔吹体操 と兵式体操とを課することになり，遊凪法す装 励せられ，頓に体操科の面目を備ふるに至った

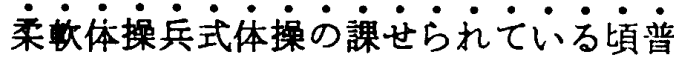
通体操法が盛に講習されて小学校に課せられる ことになった.」年)
つまり小学校体育の教材は，「兵式体操」「遊惺」 が先行し，やがてこれに「普通体操」が加えられ ていくのである。このようなことから，師籍学校 付属小学校や広島市内の一部小学校を除いて,

「普通体操」は運動会に扎いて行なわれなかった のがこの時期の特微である.

第四の特徴には，一般に運動会と服装改善とを 結びつけがちであるが，この時期の運動会開催と 服装改善とは直接には結びつかなかったことがあ げられる。広島県においては，1885 年から86年に かけて，男子の中等学校以上の生徒は洋服を着用 し始めている。これは前述の「歩兵操練科」の導 入，「兵式体操」の必修化に対応するものであっ た．小学校については，一部の学校を除いて，明 治年間を通じて洋服は着用されなかったのが一般 的状況である。たしかに一部の学校においては服 装改善の試みがなされているが，それは次のよう な困難さから出発しなければならなかった。

「其の頃最も急を要するものは，教員生徒の服 装問題であった。山県高等小学校の兵式体操は 申分ないが，尋常小学校簡易小学校の多くは， 先生は福高に紋付羽織，生徒は袂付の着物に草 履穿きであるから兵式体操に不格好なことは勿 論であるけれども，何分小学校が創立以来十余 年, 断裂令が出てから十余年のことで，尚，鬅

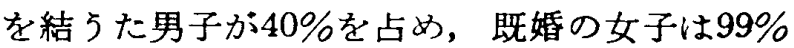
まで歯を真黒く染めていた位の時たから，小学 校の生徒に靴・洋服を揃へさせるといふことは 容易の事ではなかった.」41)

この記述は当時の風俗を伝㫕てくれて興味梁いも のがあるが，それはともかくこのよ5な事情にす かかわらず山県郡では，88 年に沼田，高宮両郡と 共同して，小学校生徒用の靴と洋服の翰旋をして いる.

「かくて広島から洋服屋と靴屋が寸法取りに郡 内を一巡した。併し出来上った洋服之靴之注全 部它行渡ったのではない，山県高等小学校の外 は, 戸河内, 加計, 戸谷, 大朝，王生の尋常小 学校だけであった。そして折角出来た洋服のホ ックが破損しても，地方に洋服屋が一軒もある ではないし，スダ広島へ町便で送らねばなら ず，靴の修縉は半年に一回位「靴直し」といふ 
男が，裏皮を担いで迴る位であったから，遂に

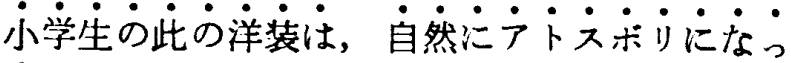
た訳である.」22

この「山県郡育誌」の著者は, 経済的視点を欠 落させてはいるすのの，当時の服装改善の困難さ をリアルに描いている。そしてたとえば山県郡高 等小学校の,「陸軍予備軍曹を任用して兵式訓練

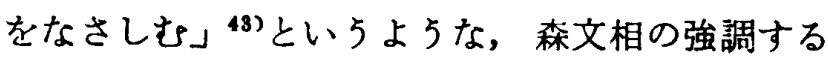
兵式体操に対する「熱病的な対応」にこそこの当 時の服装改善の背景を求めるべきものであった。

総じて初期の運動会は, 開催学校数において ま，またそのプログラムからみても，小規模なも のであったが，それだけにかえって「体育奖励」 乞い5性格が，明治期を通じて最子純粋に保たれ ていたとい主よ。

\section{III 学校運動会の变新}

広島県運動会史の初期に続く 1900 年頃までの10 作間は，学校運動会の性格が決定づけられた時期 である．大日本帝国憲法の制定 (1889年)，教育に 闵する勅語の発布 (1890年), 小学校令の改正 1890 年), 小学校祝日大祭日儀式規定の制定 1891年）等の一連の国家政策の展開によって始 志るこの時期においては, 学校運動会も一教科や 学校の行事という枠を越えて，時代の要請に答え 齐ならなくなる。

（1）運動会と儀式

初期の学校運動会の開催時期を調 べてみると， 夏季休業期間の 8 月を除いて各月に行なわれてお 门，開催時期についてはかなり恐意的であったこ 上を思わせるが，90年代以降においては，春秋に 阔定化される傾向が顕著となってくる。

1891年に制定された「小学校祝日大祭日儀式規 定」は，教育の国家統制強化の一環として学校行 柰を制度化しているところに特色がみられるが， 学校運動会からみれば，祝祭日に少ける体育奖励

（第 4 条）および儀式の地域住民への㹡大（第 6 条）に留意すべきであろ5。改正小学校令が尋常 小学校の「体操」を随意科目としたことともあい 圭って，学校体有が日常の教育活動上り年中行 事として注目されるょ5になる背蒜であった。

広島県における学校運動会と儀式との結びつき
は，91年，県内各学校で行なわれた「教育勅語腃 本拝受式」に始まる。これは前年に発布された「教 育栜語」の膡本を各学校が受領するための儀式で あったが，文部大臣訓示(4)やそれて受けた県知事 訓令45)などに指示されて，各学校では大がかりな そして“敩肃”な儀式を挙行している。そして式 後に「余興」として，もちまき，角力，運動会な どを行な5学校が少なくなかった。この「余興」の 発想についての検討は措くとしても，「余興」を 儀式に組み込まなければ，児童や地域住民を“敩 肃”な儀式に参列させることが困難であったとい らのが実態であろう．そして「平索欠席の生徒さ へも来会」9)する運動会のいわば民衆動員的性格 が，学校運動会と儀式とを結びつける大きな理由 であった。

ともあれ，1891 年以降学校運動会は，「天長節」 「創立記念日」「落成式」「戦捷記念日」などと 結びつけて開催されることが多くなり，またこれ らと関係のない運動会においても，「君が代」斉 唱や「栜語奉読」がプログラムに組み込まれた り，高官貫顕が列席するとい5よ5な形で，儀式 化していくのが一般的様相であった。

(2) 学校運動会と就学奖励

広島県の学童の就学率は, 1894 年によ 5 や 50 \%を越えるとい5状況であったから，この時期の 教育関係者の最大の関心事は就学奖励にあった。 すでに運動会の初期においても，会場までの行進 に勧学歌などを歌わせる学校8)がみられ, 就学奖 励の手段として運動会はかなり早くから着目され ている。運動会を就学奖励に利用するとい5考え は全国的傾们であって，大日本教骨会主催の全国 教育者大集会に拀いても，「就学勧奖法」が諭ぜ られ，その挂として運動会があげられてい る.5)

神石郡の連合運動会について，「結果颇る良好 にして西来聯合各校とも就学児童非常に增加し父 木野，高蓋二校の如きは校舎の改築を初むるが如 き意外の効果を奏せり」 ${ }^{10)}$ と報ぜられるほと，運

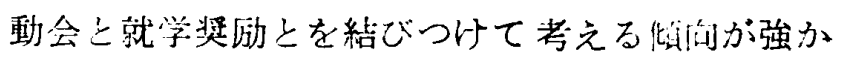
った。电ち万ん，長欠児童や不就学巟童の問題は， 年に一度か二度の運動会によって解决できる性䓄 のものではない。むしろ運動会まで利用しなけ 
ればならない汪ど，根深い問題であったと理解す べきであろ5．そして多くのばあい，運動会終了 後に「教育講演会」や「幻灯会」を催して教育の 啓蒙を四るというのが，この時代の一つのパター ンであった：運動会はこのための人集めの手段で ああった。

（3）学校運動会の変質

学校運動会が体育励よりもむしろ別の㑡面か らの期待に沿わねばならなくなってくると，当然 ながらその内容も变質を余儀なくされてくる。 そ れを端的に示すのが演技種目であろう。この時期 のプログラムを「兵式体操」「普通体操」「遊戯」 種目に大別して検討すると，「兵式体操」種目の 後退と「遊戲」種目の增加を特徽としてあげるこ とができる。

初期において重視された「兵式体操」は，1891 年以降10年間は，小学校，中等学校，師範学校の 運動会を通じてほとんど行なわれていない，この 現象は広島県だけのことではなくて，たとえば大 分県についても同様なことが報告されている. ${ }^{15)}$

「体操」が随意科目となっていた尋常小学校は別 こしても，各学校の運動会種目に「兵式体操」が姿 を消している事実は興味潹い，運動会種目か直ち に学校体育を反映しているとは限らないが，この 時期の「兵式体操」をめぐる問題の複雑さを示唆 している。高津が指摘するよ5に, ${ }^{31)}$ 森文相期に 強調された「兵式体操」が連続的には発展しなか った一つの証左でああろ5．学校令当時，「兵式 体操」に対して小学校まであが示した熱狂的と思 える歓迎ぶりも，服装改善に质られたよ5に「自 然に宁六军り」となったのである。

この「兵式体操」と対蹨的であったのが「遊䖗」 程目の急增である。く门かえし述べるように明治 期に拁ける学校伭骨の教材は，「兵式体操」「普 通体操」「逰戲」によって棈成されていたか，前 二者は，「施行規則」や「教則」の改訂のたびに， その内容が次第に細かく規定されていったのに対 して，「遊戯」の内容についてはあ音り触れられ ていなかった。つまり明治期のどちらからいえば 活苦しい体操科の授業にあって，「遊戯」だけが，

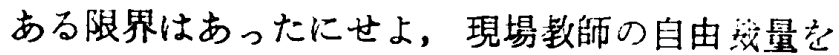
許される唯一の領域であった。このことが一方で
は現場教師による遊戱研究や多くの遊戲青の発行 を導き，他方ではその反映ともみられる学校運動 会に㧍ける「游戯」種目の多彩・多様化を生み出 したのである。

1891年から1900年までの 10年間に広島県の地方

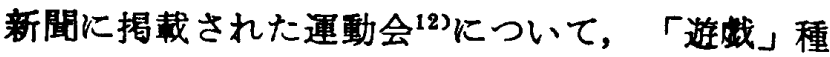
目の頻度をみると次のような順位となっている。

1.網引，2. 兔跳，3. 旗取，4. 三人三脚， 5. 障碍 物，6. 徒歩競走，7. 擬馬，8. 球投げ，9. グラン ドチェーン，10. 提灯，11. 旗送り，12. 槽転し， 13. 球拾い, 14. 十字行進, 15. 民草

初期においてはみられなかった唱歌遊战・行進 遊戲が登場してこの時期の運動会に彩りを加えて いる。また教育的遊戯の意図がどのよ5なるので あったにせよ，現実には即興的興味本位の種目が 多くなってきたことは否めない事聿であった。観 采す「普通体操」や「兵式体操」とは異なって, 日本的に消化された「遊戯」種目に対しては，自 分たちの子弟の演技を見守るとい5こと以上に共 鳴するものがあったにちがいない。

いずれにしても「遊戯」種目の増加につれて, 運動会は伸び伸びとした楽しく賑やかな一種の 「祭り」的性格を带びるよ5になってきた。これ はたしかに木下の指摘する「運動会からの教育性 の後退」26) であったが，それは学校運動会が一教 科の行事や学校行事の枠を越えて，その民衆動員 的性格のゆ光に，様々に利用されて時代の要請に 答えねばならなかったことから生じてきたもので ある。またそれは，現場の教師たちが遊戯の教育 性を自临し強調しても，もはやとどまるところを 知らず自転していく運動会の努でもあった。

\section{IV 運動会の定普と㞄動会批判}

1900年から12年までの時期には，ほ上んよ゙の学 校が連動会を行なうようになり，運動会は年中行 事として定着するが，同時にその在り方をめぐっ て批判も高まってくる.

(1) 学校運動会の定着

これまでの学校運動会は，「枍外」に占いて数 校が「进合」して間催する之いう柇式が一般的で あったが，この洔期には「校内」において「羊独」 で開催する学校が多くなってくる，広島県のばあ 
い，1903年を境として，「校内・単独」型の運動 会は，「校外・連合」型のそれを凌駕し，以後， 後者のタイプの運動会は次第に少なくなってい $\therefore$ ここ机はあらためてい5までもなく，児童生徒 数の增加や運動場の整崙などによってもたらされ たものである.1900年の改正小学校令には「体操 場」の設置が規定されているが，これによって直 ちに各学校に運動場がつくられたと速断すること はできないにしても，この時期を通じ徐々に整備 されていったことは事実である。

この時期の学校運動会のプログラムは，「遊戯」 「普通体操」種目に加えて，90 年代には努を消し ていた「兵式体操」す再び登場して，各種目の内 容は從前にも增して豊富になっていく，前章にお いてとったと同様な方法 ${ }^{13)}$ で，「遊戯」種目を頻 度順に列挙すれば次のとおりである。

1. 徒步競走，2. 障碍物，3. 二人三脚，4. 旗取， 5. 綱引，6. 提灯，7. 服装，8. 后飛，9. 一人一 脚, 10. スプーン，11. 抽鐵，12. 計算，13. 戴 亦，14. 千鳥，15. 騎馬

これらのうちとくに上位の数種目は，どの運動 㕕においてもみられるいわば運動会を象徽する 種 目として，固定化された傾向がうかがる。 そし て「徒歩競走」「障碍物」「三人三脚」「旗取」 「網引」などを中心に，「体操」種目，時々の世 相を反映した「競争遊盛」，低学年を対象とする 「唱歌逰戯」などを配列するというのが，この時 期の学校運動会プログラムを編成する基本的方式 であった。この運動会種目の固定的部分は，明治 期のみならずかなり後代まです引きつがれていく ことは注目されてよい，なぜこれらの種目が固定 化されて持続するのかといらことの検討は今後の 課題としたいが，同一の学校の運動会種目を逐年 的に調べてみても，その変化はきわめてゆるやか で，一度，年中行事化した運動会は容易にはその 内容が変わらないことを示している。

これら学校運動会の一般的傾向の中にあって， 部分的にはこの時期に特徽的ないくつかの現象が みられる，その一つは「選手競走」の出現であ る. 中等学校においてはすでに，90 年代の半ばか ら，たとえば広島中学の「チャンピオンレース」(18) の上5に，代表選手による競走が行なわれている
が，小学校において「選手競走」が一般化するの はかなり遅く，1900年代の後半からである。それ は当初，中学校が運動会に小学校選手を招待する という形で始まる．当時の中等学校のスポーッ大 会を上級学校が主催するといら形式を踏㜔したこ の試みは，卧海中学が「優勝旗競走規定」48) を制 定し記録を詳しく校友会誌に揭戴した例のよ5 に，小学校選手の招待に様々な工夫をこらして， 一種の流行とさえなった。その結果, 三次中学枍 校友会誌が告げるよ5に，「次は小学校選手競争 ……優勝旗は四年といふ四年まで，塩町の手に落 ちた。…..聞けば同校では，毎年我校の運動会が 近よると，生徒は少額酸金して，毎日鵎卵等で選 手を優待して遗る。だから選手は充分責任を自覚 して每日毎夜，数十町宛徒歩の練習をする…」33) という過熱した事態までも招くようになる。

この中学校の運動会に触発されて, やがて小学 校運動会に执いても「選手競走」が始まる。それ は内にあっては地域対抗, 外に対しては学校刘抗 という競争意識を背景として，児童・生徒や観衆 の熱狂を導き，運動会の「呼びもの」となってい く性質のものであった。

ところでこの時期の運動会における「体操」種 目は複雑な様相をみせる。「兵式体操」の復活は前 述のとおりであるが，1907 年頃からプログラムに は，「新式徒手体操」「各個演習」「徒手各個運動」 「瑞典式体操」とい5名称の種目が登場する。こ れは明らかにスウェーデン体操を示すすのであっ たが，学校によっては上記種目と「蕣鈴体操」

「球篻体操」を並行させてプログラムを編成して いるばあいもあった，スウェーデン体操導入当時 の体育事情を, 再び「山県郡教育誌」から引用す れば次のとおりであった。

「普通体操の小学校に行はれてある明治三十五 六年頃から川瀬元九郎, 井ロアク 瑞典式体操の我が国に移入せらるるありて斯界 に大なる衝動を与へた。又此の頃は体育熱の勃

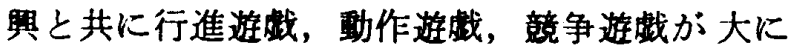
高唱せらるるに至り実祭小学教育者は其方取捨

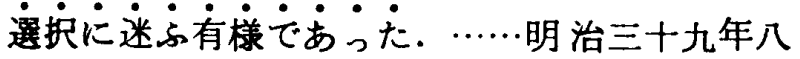
月二十三日より七日間……広島高等師範学校教 諭西村虎太郎を招聘し此の新式体操講習会を開 
催せられた.」无)

しかし講習会を開催しても「取捨選択に迷ふ」現 場教師の混乱が解消されたわけではなかった。岸 野が指摘する ${ }^{30)}$ 講習会の講師間の不統一や法規改 正に至らなかった行政的姏置の遅れなどによっ て，「普通体操」と「スウェーデン体操」の共存 といら現象を生み出したのである，学校運動会も このよ5な動きを敏感に反映したわけであった。

(2) 運動会批判

学校運動会に対する批判についてはすでに 報告

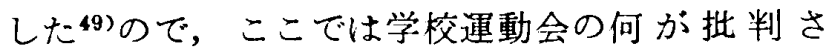
れ，何が改善されたのかといらことを要約してお きたい，総じて学校運動会批判は教育性の復権を 求めたものであったが，具体的には次のよ5な形 で取り上げられた。

第一一批判は，運動会種目の選び方に问けら れ，雑誌「坛倩教育」の表現によれば「訓練の絶 然なること」21) が問題とされている。つまり即興 的興味本位の種目に偏って，日頃の「体操」教育 の成果を発表するとい5本来の運動会の趣旨か ら，著しく逸脱しているとい5わけである。

第二は，この時期，学校運動会にも生じつつあ った一種の選手制度に対して向けられた批判であ る。広舅県師範学校長広瀨時治の, 「各学校に於て 行はるる運動会は其校に於て技芸熟達したるるの のみを撰手として之に当らしめ観客をして興を買 はしむるが如き恰も興行的の行為ありて…....111 という批判が典型的な例である。

第三には，運動会開催の経費に対する批判があ る. 運動会費用の軽減法を議題とした山県郡の小 学校長会同 (1904 年)47) の例にみられるよ5に, 過熱し華美となったこの時期の運動会は，その経 費の面からす問題となってくる。そして具体策と して提案されたのが，筫品廃此であった。

これらの批判に対して運動会の全面的刷新を試 みた学校はごく限られていた。この時期に創設さ れた広島高師（1902年創立）の従前の運動会との 区別を意識した「体操科演習会」22) や県立高女の 春には運動会，秋には「体操演習会」 ${ }^{17)}$ とい5試 みは，たしかに運動会の在り方についての学校当 局の模索を示するのであったししかしながら，多 くの学校では，せいぜいブログラムに若干の修正
を加えたり，賞品を廃止するとい5いわば運動会 の部分修正をすって批判に答えるとい5のが一般 的傾问であった：それは運動会が，すは中日常の 教有活動の延長としてはとらえがたい，教育の枠 組を越えた行事となったことを示するのであろ 5 .

\section{むす ひ}

考察結果は次のよ5に要約される.

1. 学校運動会は体育奖励のために始められ， 初期の数年間はこの性格が比較的純粋に維持 された。

2. 1890 年頃から学校運動会はその民衆動員的 性格のために様々に利用され，学校行事から 地域社会の行事へと変啠を余儀なくされた。

3.1900年以降，運動会の教育性の回復を求め て批判が高まるが，教育の枠組を越えてしま った運動会は，教育関係者の努力にもかかわ らず，改善されることなく独自の步みを続け た。

運動会が学校から地域社会へ㹡大ざれる過程に ついては十分に検討することができなかった。今 後の課題としたい.

文献

1）荒井貞光「日本人とスポーツについての一考察— 学校運動会の歴史と社会的意味」九州大学体育学研究。 $4 \sim 4: 1 \sim 6,1971$.

2）大日本教育会雓誌，24:75，1885.

3） 同上 $31: 58 \sim 59,1886$.

4) 同上 $29: 69 \sim 72,1886$.

5）同上別巻 1: 193, 1895.

6) 藤山豊・福島烃二, 小学校に於りる体育上の実腙的 施設之運功会，初版，宝文館，p.170，1912.

7）芸借日日新閒，1887，12，1.

8）同上 $1888,12,1$.

9）同上 $1892,4,19$.

10）同上 $1899,5,13$.

11) 同上 $1901,11,5$.

12）同上 $1891 \sim 1900$.

13) 同上 $1901 \sim 1912$.

14）平野捻「大分県における明治体青史の研究一一罣的 会, 遠足飞ついて」大分大学程詥詥，23〜 $4: 69 \sim$ 
102, 1971.

15）同上 86.

16）広島毒常中学校同空会誌「䋥域」2：60. 1897.

17）広島高等女学校校友会誌「真己とのとく」6：118～ 19. 1908.

18）広島県教育委員会, 広島県教育八十年誌, 初版, 同 委員会, pp. 178 83, 1935.

19）広島県師籍学校，六十年回㟲録，初版，同校，第 3 糄, pp. 11 12. 1935.

20)

21）㕕島県私立教育会機関誌「芸備教育」18：3～4, 1905.

22）広島高等師籍学校校友会誌，9：1～18，1908.

23）今村部雄, 十九世紀於ける日本体育の研究, 初版, 不昧堂害店, pp. 968〜79. 1967.

24）同上, p.851.

25）同上, p.889.

26）木下秀明, 日本体育史研究序説, 初版, 不昧堂出版, p. $227,1971$.

27）岸野雄三「遈動会の歴史」カリキュラム，臨時增刊 号: $4 \sim 6,1958$.

28）岸野雄三「日本の運動会の由来と特色」体育科教育, $9: 2 \sim 5,1964$.

29）岸野婎三，体有史，初版，大修館書店， p.199, 1973.

30）岸野雄三, 近代日本学校体青史, 初版, 東洋館出版 社, p. 82, 1959.
31）高洋勝「国民教育制度成立期の学校体育政策」体育 学研究, $17 \sim 3: 121 \sim 28.1972$.

32）教育史被策会，明治以降教育制度発達史第一巻，二 版, 竜吟社, p.716, 1964.

33）三次中学校校发会誌「巴快」，15：76.1911.

34）文部省第四年報，p. $217 ， 1876$.

35）文部省第二年報，p.314，1874。

36）文部省第三年報， p. $514 ， 1875$.

37）文部省第十年報，P. $612 ， 1882$.

38）文部省第十一年報， p.609，1883.

39）名田富田郎，山鼠郡教育誌，初版，山罢郡教育会， p. $935,1943$.

40) 同上, pp. 935 37.

41）同上, p. 166.

42）同上, p.167.

43）同上, p.166.

44）同上, p.176.

45）同上, p.176.

46）同上, p. $938 \sim 39$.

47）同上, p. 287.

48）忠海中学校校友会誌「同遊」，11：79，1906.

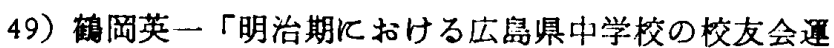
動部认ついて」体育篎研究, 18〜1, 9〜22, 1973.

50）山本信良・今野敏彦, 近代教育の天眰制イデオロギ 一，第1刷，新泉社，1973.

51) 同上, p.364. 